\title{
HUBUNGAN KETERBUKAAN STATUS HIV DENGAN STIGMA DIRI PADA ORANG DENGAN HIV/AIDS
}

\author{
Nurullah Ika Pujilestari ${ }^{*}$, Wira Daramatasia ${ }^{2}$, Abdul Qodir $^{3}$ \\ ${ }^{1}$ STIKES Widyagama Husada Malang \\ ${ }^{2}$ STIKES Widyagama Husada Malang \\ ${ }^{3}$ STIKES Widyagama Husada Malang \\ Abstract
}

Correspondingauthor:

Nurullah Ika Pujilestari

STIKES Widyagama Husada Malang

Email:nurulcha14@gmail.com

\begin{abstract}
Background: The responses of PLWHA after knowing that they have HIV/AIDS are shock, anxiety, fear, worry, guilt, and self-blame. PLWHA still have a fear of disclosing their disease status because of the negative stigma against themselves regarding HIV / AIDS. Objective: To examine the correlation between HIV status disclosure and self-stigma among PLWHA in Jombang Care Center Plus (JCC+) Jombang Regency. Research Methods: The research design was analytical survey correlation with cross-sectional approach. The samples were taken by purposive sampling with a sample size of 55 respondents living with HIV at the Jombang Care Center (JCC+). The research instrument used were the Self Disclosure Scale questionnaire and the stigma questionnaire Selected Berger Scale. Data analysis used Pearson Correlation test. Results: The results of data analysis showed the magnitude of the correlation coefficient $r=0.200$ with a significant level of $p=0.143$ ( $p>0.05)$, meaning that there was no significant correlation between HIV status disclosure and selfstigma among PLWHA in Jombang Care Center Plus (JCC +) Jombang Regency. Conclusion: It can be concluded that there is no correlation between disclosure of HIV status and self-stigma among PLWHA in Jombang Care Center Plus (JCC+) Jombang Regency. Suggestion: P LWHA should develop more positive self-concepts such as trying to socialize with other people by joining the community that can provide support and encouragement to PLWHA.
\end{abstract}

Keywords: HIV/AIDS, Disclosure Status, Self Stigma.

\begin{abstract}
Abstrak
Latar Belakang: Respon ODHA setelah mengetahui bahwa dirinya terkena HIV/AIDS ialah syok, cemas, takut, khawatir, rasa bersalah, dan menyalahkan diri sendiri. ODHA masih mempunyai ketakutan untuk mengungkapkan status penyakitnya karena adanya stigma negatif terhadap diri sendiri mengenai HIV/AIDS. Tujuan: Mengetahui hubungan keterbukaan status HIV dengan stigma diri pada ODHA di Jombang Care Center Plus (JCC+) Kabupaten Jombang. Metode Penelitian: Desain penelitian adalah survey analitik korelasi dengan pendekatan CrossSectional. Teknik sampel yaitu Purposive Sampling dengan jumlah sampel 55 responden ODHA di Jombang Care Center (JCC+). Instrumen penelitian menggunakan kuesioner Self Disclosure Scale dan kuesioner skala stigma Selected Berger Scale. Analisa data menggunakan uji Korelasi Pearson. Hasil Penelitian: Hasil analisis data menunjukkan besarnya koefisien korelasi $r=$ 0,200 dengan taraf signifikan $\mathrm{p}=0,143(\mathrm{p}>0,05)$, artinya tidak ada hubungan yang bermakna antara keterbukaan status HIV dengan stigma diri pada ODHA di Jombang Care Center Plus (JCC+) Kabupaten Jombang. Kesimpulan: Dapat d simpulkan bahwa tidak ada hubungan antara keterbukaan status HIV dengan stigma diri pada ODHA di Jombang Care Center Plus (JCC+) Kabupaten Jombang. Saran: ODHA lebih mengembangkan konsep diri positif seperti mencoba bersosialisasi dengan orang lain dengan cara bergabung dengan orang-orang yang dapat memberikan dukungan dan semangat pada ODHA.
\end{abstract}

Kata Kunci: HIV/AIDS, Keterbukaan Status, Stigma Diri. 


\section{PENDAHULUAN}

HIV/AIDS merupakan masalah kesehatan masyarakat terbesar di dunia. HIV/AIDS terdapat hampir di semua negara di dunia tanpa kecuali termasuk Indonesia. Data surveilans dari UNAIDS tahun 2019, orang dengan HIV di dunia sebanyak 37,9 juta jiwa. Berdasarkan hasil laporan Kemenkes RI bulan Juni 2019 terdapat jumlah kasus HIV yang dilaporkan dari tahun 2005 sampai tahun 2019 mengalami peningkatan setiap tahunnya. Jumlah kumulatif kasus HIV yang dilaporkan sampai dengan Juni 2019 sebanyak 349.882 dengan jumlah tertinggi yaitu Jakarta, diikuti Jawa Timur, Papua, Jawa Barat dan Jawa Tengah. Di Provinsi Jawa Timur terdapat 51.990 penderita HIV (Kemenkes RI, 2019). Dari jumlah tersebut paling tinggi terdapat di Surabaya, Malang dan Jombang. Jumlah penderita HIV/AIDS di Jombang berdasarkan data yang dirilis Komisi Penanggulangan AIDS (KPA) kabupaten Jombang (2019), sejak 1999 - Juni 2019 jumlah penderita HIV/AIDS berhasil dideteksi sebanyak 1.504 orang dengan penyebaran hampir merata ada di setiap kecamatan. Angka ini diperkirakan akan meningkat menjadi $0,16 \%$ pada tahun 2020 .

Pada penelitian sebelumnya diteliti jumlah yang membuka status penyakit (HIV) pada orang terdekatnya, ditemukan 19 dari 40 ODHA yang sudah membuka status HIV kepada keluarga dan orang terdekat (Khububiyah, 2018). Untuk stigma diri dari 55 ODHA di KDS JCC+ ditemukan 13 memiliki stigma baik, 41 cukup, dan 1 ODHA dengan stigma diri buruk (Mariyamah, 2019). Meskipun banyak upaya telah dilakukan untuk meningkatkan tingkat identifikasi ODHA dengan kualitas dan aksessibilitas layanan kesehatan, ada banyak hambatan sosial, ekonomi, budaya, dan sistem kesehatan yang menghambat proses. Stigma terkait HIV/AIDS adalah salah satu hambatan yang paling disorot dalam hal ini.
Menurut Devito (2011) self disclosure atau pengungkapan diri merupakan jenis komunikasi yang mengungkapkan informasi tentang diri sendiri kepada orang lain secara aktif disembunyikan. Selama ini HIV/AIDS dikaitkan dengan penyakit kutukan, sehingga ketika seseorang terinfeksi penyakit tersebut tidak jarang masyarakat menganggap tindakan yang dilakukan adalah buruk dan kadang tidak beragama. Selain itu masyarakat yang menjauh pada ODHA dengan alasan ketakutan akan penularan penyakit tersebut. Itulah sebabnya ODHA cenderung menutup diri dari masyarakat maupun keluarganya sendiri (Hemawati, 2009). Suriana (2013) menemukan beberapa ODHA mampu melakukan pengungkapan diri, hasil yang didapat oleh ODHA setelah melakukan pengungkapan diri mengenai status HIVnya kepada keluarganya adalah keluarga memberi dukungan positif kepada ODHA untuk selalu melakukan pengobatan, meskipun pada awal pengungkapan diri sempat mengalami pengucilan oleh keluarga. Pengungkapan diri yang dilakukan ODHA karena mempunyai dorongan dan tujuan tertentu. Manfaat dari pengungkapan diri yang dirasakan oleh subjek kepada orang-orang terdekatnya yaitu subjek merasa tenang, beban pikiran mengenai penyakitnya berkurang, bisa membagi pengalaman kepada yang mendengarkan ceritanya supaya berhatihati dan tidak tertular seperti dirinya.

Banyak faktor yang mempengaruhi persepsi ODHA terhadap stigma. Penelitian sebelumnya telah melaporkan jenis kelamin, faktor usia, kelas sosial, dukungan sosial, tingkat stereotip, dan rute penularan HIV sebagai faktor yang mempengaruhi stigma yang dirasakan oleh ODHA (Xu,. et al, 2017). Stigma terkait HIV adalah hasil dari interaksi yang kompleks antara faktor sosial, kontekstual dan diri. Aksesibilitas pelayanan kesehatan, dukungan sosial, ketersediaan informasi yang sesuai dan masalah ekonomi, budaya, 
dan politik adalah beberapa faktor sosial yang mempengaruhi persepsi stigma oleh ODHA. Dalam kategori faktor kontekstual, kondisi kehidupan, penggunaan narkoba dan / atau alkohol, status kesehatan, waktu sejak diagnosis, dan keadaan keluarga lebih disorot dalam hal ini (Stangl, A., Brady, L., Fritz, 2012).

Berdasarkan studi pendahuluan yang dilakukan peneliti tanggal 17 November 2019 dengan pihak Kelompok Dukungan Sebaya JCC+. Sebagian penderita HIV yang tergabung dalam JCC+ masih takut untuk mengungkapkan status penyakitnya kepada keluarga dan orang terdekat karena alasan takut jika keluarga dan orang terdekat tidak mau menerima keadaannya dan ODHA akan mendapat diskriminasi ataupun stigma yang berhubungan dengan penyakit yang dideritanya. Stigma yang terjadi di masyarakat, HIV/AIDS adalah penyakit yang mematikan dan tidak ada obatnya. Stigma diri pada ODHA setelah mengetahui bahwa dirinya terkena HIV/AIDS ialah syok, cemas, takut, khawatir akan menularkan penyakitnya kepada orang terdekat, rasa bersalah, dan ada juga yang berfikir bahwa itu adalah teguran untuk dirinya. ODHA masih mempunyai ketakutan untuk mengungkapkan status penyakitnya karena adanya stigma negatif terhadap diri sendiri mengenai HIV/AIDS, sehingga ODHA cenderung menutup diri dari lingkungan masyarakat tanpa memberitahu keadaan yang sebenarnya dan hanya dengan orang-orang tertentu ODHA mau berbagi.

Dengan demikian, penulis tertarik untuk melakukan penelitian di Jombang Care Center tentang Keterbukaan status HIV kepada masyarakat dengan stigma diri pada ODHA di Jombang Care Center Plus (JCC+).

\section{METODE}

Subjek penelitian ini adalah ODHA yang bergabung di KDS JCC+, berusia $\geq 18$ tahun, dalam kondisi baik atau tidak mengalami penurunan kesadaran, telah mendapat terapi $\mathrm{ARV} \geq 6$ bulan, anggota dari JCC + , dan telah menandatangani informed consent. Desain penelitian yang digunakan yaitu analitik observasional dengan pendekatan Cross Sectional. Responden berjumlah 55 ODHA yang diambil dari 550 ODHA yang bergabung di KDS JCC+ berdasarkan rumus Arikunto. Keterbukaan Status dikaji dengan menggunakan kuesioner kuesioner self disclosure scale. Stigma diri ODHA dikaji menggunakan kuisioner Selected Berger Scale.

\section{HASIL}

\section{Distribusi Karakteristik Responden}

Karakteristik Subjek Penelitian ini terdiri dari usia jenis kelamin, pendidikan, pekerjaan, status pernikahan, lama terdiagnosa, cara penularan, keterbukaan status, dan stigma diri dapat dilihat pada tabel 1 .

Tabel 1. Karakteristik Responden

\begin{tabular}{lcc}
\hline \multicolumn{1}{c}{ Variabel } & $\begin{array}{c}\text { Jumlah } \\
(\mathbf{n})\end{array}$ & $\begin{array}{c}\text { Prosentase } \\
(\boldsymbol{\%})\end{array}$ \\
\hline Usia & 6 & 10,9 \\
$17-25$ tahun & 39 & 70,9 \\
26-45 tahun & 10 & 18,2 \\
46-65 tahun & & \\
Jenis Kelamin & 31 & 56,4 \\
Laki-laki & 24 & 43,6 \\
Perempuan & & \\
Pendidikan & 7 & 12,7 \\
SD & 13 & 23,6 \\
SMP & 27 & 49,1 \\
SMA & 8 & 14,6 \\
Akademi/Universitas & & \\
Status Pekerjaan & 42 & 76,4 \\
Bekerja & 13 & 23,6 \\
Tidak Bekerja & & \\
Status Pernikahan & 23 & 41,8 \\
Menikah & 20 & 36,4 \\
Belum menikah & 11 & 20 \\
Janda & 1 & 1,8 \\
Duda & & \\
& &
\end{tabular}




$\begin{array}{lcc}\text { Lama terdiagnosa } & & \\ <1 \text { tahun } & 12 & 21,8 \\ 1-5 \text { tahun } & 29 & 52,7 \\ 5-10 \text { tahun } & 12 & 21,8 \\ >10 \text { tahun } & 2 & 3,6 \\ \text { Cara Penularan } & & \\ \text { Hubungan Seksual } & 42 & 76,4 \\ \text { Terinfeksi darah } & 0 & 0 \\ \text { Jarum suntik } & 0 & 0 \\ \text { Seks sesama jenis } & 13 & 23,6 \\ \text { Keterbukaan Status } & & 78,2 \\ \text { Terbuka } & 43 & 21,8 \\ \text { Tidak terbuka } & 12 & \\ \text { Stigma Diri } & & 21,8 \\ \text { Baik } & 12 & 34,5 \\ \text { Cukup } & 41 & \\ \text { Buruk } & 2 & \\ \end{array}$

\section{Hasil Analisa Bivariat}

Analisa dilakukan dengan menggunakan uji korelasi Pearson, dengan hasil sebagai berikut:

Tabel 2

Hubungan keterbukaan status dengan stigma diri pada ODHA di JCC+ Kab. Jombang $(n=55)$

\begin{tabular}{cc}
\hline & Skor Stigma Diri \\
\hline Skor Keterbukaan Status & $\mathrm{r}=0,200$ \\
$\mathrm{p}=0,143$ \\
$\mathrm{n}=55$ \\
\hline
\end{tabular}

Pada tabel diatas, diperoleh nilai $\mathrm{p}=0,143(p>0,05)$ yang menunjukkan bahwa korelasi antara keterbukaan status dengan stigma diri pada Orang dengan HIV/AIDS (ODHA) di Jombang Care Center Plus (JCC+) Kabupaten Jombang tidak bermakna. Nilai correlation coefficient sebesar 0,200 menunjukkan korelasi positif dengan kekuatan korelasi yang lemah karena mendekati angka 0.

\section{PEMBAHASAN}

\section{Karakteristik umum subjek penelitian ODHA}

Pada Tabel 1 menunjukan karakteristik responden ODHA di KDS JCC+ berdasarkan usia, jenis kelamin, tingkat pendidikan, status pekerjaan, status pernikahan, lama terdiagnosa HIV/AIDS, cara penularan, keterbukaan status, dan stigma diri.

Berdasarkan usia yang didapat responden yang tergabung dalam JCC+ paling banyak usia 26-45 tahun yaitu sebanyak 39 responden $(70,9 \%)$. Hal ini sesuai dengan data dari (Dinas Kesehatan, 2018), berdasarkan jumlah penderita HIV/AIDS pada tahun 2018 terdapat 173 kasus baru HIV/AIDS dengan presentase kasus tertinggi terdapat pada golongan usia 25-49 tahun yaitu sebanyak $71,7 \%$. Hal ini juga didukung oleh Finnajakh, Meilani, \& Setiyawati (2019) dalam jurnal "Hubungan Tingkat Pengetahuan dan Persepsi Dengan Stigma Masyarakat Terhadap Odha di Desa Pandowoharjo, Kecamatan Sleman, Kabupaten Sleman" dengan total 150 responden didapat usia paling banyak yaitu 26 - 45 tahun yaitu sebanyak 89 orang dan jika dipresentasikan yaitu sebanyak 59,3\%. Kelompok usia ini merupakan kelompok usia produktif dan aktif melakukan berbagai macam aktifitas dan kontak dengan orang lain, tanpa terkecuali dengan orang yang terinfeksi HIV/AIDS (Ramadhani, 2017). Selain itu, produksi hormon seksual telah matang sehingga aktifitas seksual yang tak terkendali menyebabkan perilaku seksual yang bersiko sehingga dapat menjadi sumber penularan (Fadli, 2015).

Berdasarkan jenis kelamin responden, mayoritas responden yang paling banyak adalah adalah yang berjenis kelamin laki-laki yaitu sebanyak $31(56,4 \%)$ responden, sedangkan yang berjenis kelamin perempuan adalah 24 responden $(43,6 \%)$. Hasil dari penelitian ini didukung penelitian yang dilakukan oleh Pourmarzi, Khoramirad, \& Gaeeni (2017) dalam jurnal yang berjudul "Perceived Stigma in People Living With HIV in Qom" dengan jumlah responden 118 orang, dari hasil penelitian tersebut didapat bahwa terdapat 75 responden $(63,6 \%)$ berjenis kelamin laki-laki dan 43 responden $(36,4 \%)$ yang berjenis kelamin perempuan. Laki-laki lebih bersiko terkena HIV dan AIDS karena faktor resiko HIV/AIDS dominan pada laki-laku. Hasil penelitian ini selaras penelitian Laksana \& Lestari (2010) yang 
menyatakan bahwa laki-laki homoseksual memiliki resiko tertular HIV/AIDS lebih besar daripada lakilaki heteroseksual, khususnya melalui perilaku seksual beresiko, seperti hubungan seks lebih dari satu partner dan seks anal.

Dari hasil penelitian ini diketahui bahwa responden yang paling banyak memiliki tingkat pendidikan SMA yaitu sebanyak 27 responden $(49,1 \%)$. Hasil dari penelitian ini juga didukung oleh Finnajakh et al., (2019) dengan jumlah responden sebanyak 150 orang, dimana menjelaskan bahwa ratarata penderita HIV banyak terjadi pada mereka dengan pendidikan terakhir SMA yaitu sebanyak 101 responden atau jika dipresentasikan menjadi 67,3\%. SMA termasuk dalam kategori pendidikan menengah. Pengetahuan tentang kesehatan masih kurang pada tingkat pendidikan ini, sehingga belum mengetahui risiko tinggi serta penularan HIV/AIDS (Widayanti, $\mathrm{dkk}, 2018)$.

Penderita atau responden yang tergabung di Jombang Care Center plus (JCC+) kabupaten Jombang banyak yang sudah bekerja dengan jumlah 42 responden atau jika dipresentasikan menjadi 74,6\% dan responden yang belum bekerja didapat data ada 13 responden jika dipresentasikan menjadi 23,6\%. Hasil penelitian ini juga sama dengan yang dilakukan oleh Lisnawati (2016) dalam jurnal "Hubungan stigma, depresi dan kelelahan dengan kualitas hidup pasien HIV/AIDS di klinik veteran Medan" dimana dalam penelitian tersebut peneliti menggunakan responden sebanyak 78 orang dan didapat hasil bahwa responden yang menderita HIV/AIDS banyak yang sudah bekerja yaitu terdapat 59 responden yang bekerja atau jika di presentasikan menjadi 75,6 \% dan yang tidak bekerja terdapat 19 responden dan jika dipresentasikan menjadi 24,4 \%. Tingginya kasus HIV/AIDS bila dikaitkan dengan pekerjaan, dapat diasumsikan bahwa orang yang bekerja dan mempunyai penghasilan sendiri cenderung dapat menjadi faktor pendorong untuk melakukan apa saja sesuai keinginannya dengan penghasilannya, termasuk seks bebas yang sebenarnya merupakan perilaku seks berisiko terhadap rentannya infeksi HIV (Kambu Y, 2015).

Berdasrkan status pernikahan paling banyak yang sudah menikah yaitu sebanyak 23 responden $(41,8 \%)$. Hasil penelitian ini juga sama dengan yang dilakukan oleh Lubis, dkk (2016) dalam jurnal "Hubungan stigma, depresi dan kelelahan dengan kualitas hidup pasien HIV/AIDS di klinik veteran Medan" dimana dalam penelitian tersebut peneliti menggunakan responden sebanyak 78 orang dan didapat hasil bahwa responden yang menderita HIV/AIDS banyak yang sudah menikah yaitu terdapat 46 responden yang berstatus menikah atau jika dipresentasikan menjadi $59 \%$, belum menikah 20 responden jika dipresentasikan menjadi 25,6\%, dan yang berstatus janda atau duda didapat ada 12 orang jika dipresentasikan menjadi 15,4\%. Perkawinan dan kesetiaan tidak cukup melindungi mereka dari terinfeksi HIV (Llano et al., 2006). Tingginya angka kasus ODHA yang sudah menikah dapat disebabkan karena penularan HIV melalui kontak seksual dari pasangannya (suami/istri). Oleh karena itu, informasi kesehatan tentang pentingnya tidak melakukan seks bebas dan setia pada satu pasangan menjadi satu hal yang wajib dilakukan.

berdasarkan lama diagnosa paling banyak yaitu yang telah menderita HIV selama 1-5 tahun sebanyak 29 responden $(52,7 \%)$. Hasil penelitian ini sesuai dengan penelitian yang dilakukan oleh Egbe et al, (2020), dalam jurnal "Stigmatization among People Living with HIV/AIDS at the Kumba Health District, Cameroon" dimana dalam penelitian tersebut digunakan 385 responden dan didapat hasil bahwa ODHA yang sudah terdiagnosa $\$ 5$ tahun yaitu sebanyak 294 responden jika dipresentasikan menjadi 
$76,4 \%$. Namun, data responden berdasarkan lamanya seseorang terdiagnosa penyakit HIV/AIDS dikatakan positif belum bisa dipastikan, karena ada kemungkinan responden tertular HIV terjadi sebelum mereka mengetahui di dalam tubuhnya terdapat virus HIV. Karena sebagian besar ODHA mengetahui bahwa mereka terkena HIV positif ketika mereka melakukan pemeriksaan di rumah sakit saat mereka mengalami atau timbul gejala-gejala HIV/AIDS (Wiyati, 2019).

Berdasarkan cara penularan HIV/AIDS hasil penelitian menunjukkan mayoritas adalah melalui hubungan seks (seks bebas) sebanyak 42 orang $(76,4 \%)$. Hasil penelitian ini sesuai dengan penelitian yang dilakukan oleh Wira Daramatasia (2017), dalam jurnal "Hubungan Jumlah CD4 Dengan Kualitas Hidup Pada Orang Dengan HIV/AIDS (ODHA) di Jombang Care Center Plus" dimana dalam penelitian tersebut digunakan 79 responden dan didapat hasil bahwa cara penularan melalui hubungan seks (seks bebas) sebanyak 49 responden jika dipresentasekan menjadi 62\%. Pada tahun 2016 sekitar 63\% remaja di Indonesia melakukan seks bebas (Jovian, 2016). Berawal dari tidak sengaja melihat gambar porno, lalu meningkat menjadi melakukan perbuatan seks bebas sampai akhirnya mengalami HIV \& AIDS. Perlunya dampingan dan pengawasan orang tua sejak dini menjadi faktor penting agar anak tidak melakukan seks bebas di kemudian hari. Selain itu, peran guru di sekolah juga penting dalam mengatur pola pergaulan anak hingga usia remaja.

Dari penelitian yang sudah dilakukan dengan total 55 responden orang dengan HIV/AIDS di Jombang Care Center Plus (JCC+), didapatkan hasil 43 dari 55 responden terbuka kepada orang lain. Penelitian yang dilakukan sejalan dengan penelitian oleh Dhea et al., (2017) menyebutkan bahwa mayoritas $36(72 \%)$ ODHA terbuka tentang status
HIV/AIDS dari 50 responden. Pengungkapan status HIV/AIDS yang dilakukan tidak hanya mencakup isu mengenai HIV/AIDS, tetapi juga mencakup keseharian, penilaian, pandangan, maupun perasaan pribadi yang dimiliki ODHA. Orang-orang yang mendapatkan pengungkapan merupakan orang yang sangat dipercaya ataupun memiliki kedekatan emosional. Pengungkapan diri mendapatkan reaksi yang positif, berupa pemberian dukungan sosial, baik yang bersifat emosional (moral) maupun praktikal (materil) (Tambunan, 2017).

Dari penelitian yang sudah dilakukan di Jombang Care Center Plus (JCC+) dengan total 55 responden orang dengan HIV/AIDS, didapatkan hasil 41 dari 55 responden mengalami stigma cukup .Penelitian yang dilakukan sejalan dengan penelitian oleh Ibrahim, Kombong, \& Sriati, (2019) menyebutkan bahwa 21 dari 30 ODHA memiliki stigma diri cukup. Hasil penelitian ini juga didukung dengan hasil penelitian yang dilakukan Syahrina \& Pranata (2018) yang menyatakan 31 dari 40 ODHA memiliki stigma diri sedang atau cukup. Setiap responden memiliki ketahanan psikologis yang berbeda-beda sebagai salah satunya adalah stigma dari masyarakat yang juga bisa menjadi faktor ODHA memiliki stigma diri cenderung negatif. Stigma berawal dari adanya pemahaman yang salah mengenai anggapan bahwa HIV/AIDS merupakan penyakit yang menjijikan yang menjangkiti orang yang menyimpang perilaku seksualnya (Ramani \& Urias, 2018).

\section{Hubungan Keterbukaan Status Dengan Stigma Diri pada ODHA}

Berdasarkan hasil uji hipotesis yang telah dilakukan sebelumnya menggunakan teknik analisis data Pearson. Hasil analisis data menunjukkan bahwa nilai $p=0,143(\mathrm{p}>0,05)$ yang mengartikan bahwa 
variabel keterbukaan status HIV tidak memiliki hubungan terhadap variabel stigma diri. Berdasarkan hal tersebut, hipotesis yang diajukan dalam penelitian ini ditolak. Tidak adanya hubungan yang kuat serta tidak signifikan antara variabel keterbukaan status HIV dengan stigma diri dapat dilihat dari hasil penelitian serta beberapa alasan lain yang tidak mampu menjelaskan bagaimana kedua variabel tersebut dapat saling mempengaruhi secara signifikan. Sebagai contoh varibel 1 adalah keterbukaan status dan variabel 2 adalah stigma diri, namun dalam hasil penelitian setelah dilakukan uji statistik pearson menunjukkan bahwa tidak ada hubungan yang bermakna antara kedua variabel. Yang mana seharusnya jika ODHA tidak membuka status penyakitnya maka stigma dirinya akan semakin buruk atau negatif.

Namun hasil penelitian yang telah dilakukan oleh peneliti menunjukkan tidak ada hubungan yang antara keterbukaan status HIV dengan stigma diri pada ODHA di JCC+ Kabupaten Jombang. Maka hipotesis (H0) diterima yaitu tidak ada hubungan yang bermakna antara keterbukaan status HIV/AIDS dengan stigma diri pada ODHA di Jombang Care Center Plus (JCC+).

Hal ini sesuai dengan penelitian yang dilakukan oleh Li, Chen, \& Yu (2016) dalam jurnal yang berjudul "Disclosure appraisal mediating the association between perceived stigma and HIV disclosure to casual sex partners among HIV + MSM : a path model analysis" dalam jurnal tersebut menjelaskan bahwa perceived stigma atau stigma diri memiliki hubungan negatif dengan sikap, niat, dan perilaku pengungkapan status. Penelitian yang dilakukan peneliti hanya mencakup responden dengan lingkup kecil dan belum memenuhi jawaban dari seluruh ODHA. Penelitian dengan responden lingkup lebih luas memungkinkan untuk didapatkan hasil yang berbeda.

Faktor lain yang berhubungan dengan keterbukaan status HIV pada penelitian yang dilakukan oleh Gunawan (2015), pada penelitian tersebut peneliti mengungkapkan bahwa terdapat hubungan antara keterbukaan ODHA pada pasangan dengan tindakan pencegahan penularan HIV/AIDS (melalui safer-sex dan PMTCT) pada keluarga oleh ODHA. Karena ODHA yang terbuka cenderung akan melakukan tindakan pencegahan penularan HIV/AIDS yang tidak berisiko menularkan dibandingkan dengan ODHA yang tidak terbuka. Untuk faktor lain yang berhubungan dengan stigma diri pada ODHA dalam penelitian yang dilakukan oleh Syahrina \& Pranata (2018) dengan penelitian tentang "Stigma Internal Hubungannya Dengan Interaksi Sosial Orang Dengan HIV/AIDS di Yayasan Taratak Jiwa Hati Padang" yang menyatakan adanya hubungan antara stigma internal dengan interaksi sosial Orang Dengan HIV/AIDS yang berada dalam pendampingan Yayasan Taratak Jiwa Hati Padang.

Namun pendapat ini berlawanan dengan penelitan yang dilakukan oleh Overstreet, et al (2013) yang mengungkapkan bahwa stigma diri sangat berhubungan dengan pengungkapan status HIV, terutama pada pasangan seksual terakhir dan keluarga terdekat. Stigma menjadi faktor yang paling utama dan paling besar yang dihadapi oleh ODHA untuk dapat mengungkapkan status HIVnya (Bilardi et al., 2019). Hal ini menyatakan bahwa banyak faktor yang berhubungan dengan keterbukaan status HIV maupun stigma diri pada ODHA. Sesuai dengan data-data yang didapat, hasil setiap penelitian bisa saja berbeda. 


\section{KESIMPULAN DAN SARAN}

\section{Kesimpulan}

Kesimpulan yang didapatkan berdasarkan hasil penelitian yang telah dilakukan peneliti adalah sebagai berikut :

1. Jumlah ODHA di Jombang Care Center Plus (JCC+) kabupaten Jombang yang sudah membuka status penyakit berjumlah 43 responden dan yang tidak membuka status penyakitnya ada 12 responden.

2. Stigma Diri pada ODHA di JCC+ Kab. Jombang sebagian besar memilki stigma diri cukup dengan jumlah responden 41 (74,5\%).

3. Hubungan antara keterbukaan status dengan stigma diri pada Orang dengan HIV/AIDS (ODHA) di Jombang Care Center Plus (JCC+) Kabupaten Jombang tidak bermakna, dengan nilai signifikan $p 0.143(\mathrm{p}>0,05)$.

\section{Saran}

Bagi ODHA diharapkan untuk lebih mengembangkan konsep diri positif seperti mencoba bersosialisasi dengan orang lain dengan cara bergabung dengan orang-orang yang dapat memberikan dukungan dan semangat pada ODHA. ODHA juga harus menambah wawasan tentang HIV dan AIDS seperti seminar atau penyuluhan sehingga menjadikan stigma pada ODHA menjadi positif, menjalani hidup lebih percaya diri, mampu mengembangkan diri, dan meningkatkan kualitas hidup.

Diharapkan anggota keluarga dapat memberikan perhatian, semangat, motivasi dan menghibur anggota keluarganya yang memiliki status penyakit HIV/AIDS. Kemudian selalu mencari tau informasi mengenai penyakit HIV/AIDS, sehingga menambah wawasan keluarga tentang penyakit yang diderita oleh anggota keluarga.

\section{UCAPAN TERIMA KASIH}

Peneliti mengucapkan terima kasih kepada bapak dan ibu dosen STIKES Widyagama Husada, Civitas akademika STIKES Widyagama Husada yang senantiasa memberi dukungan, responden ODHA KDS JCC+ Kabupaten Jombang yang telah bersedia menjadi subjek penelitian, dan pihak-pihak lain yang telah membantu hingga penelitian dan penulisan artikel ini dapat terlaksana dengan baik.

\section{DAFTAR RUJUKAN}

Abraham Maslow. (2006). On Dominace, Self Esteen and Self Actualization. Ann Kaplan: Maurice Basset.

Anggraeni,D.M \& Saryono. (2013). Metodelogi Penelitian Kualitatif dan Kuantitatif dalam Bidang Kesehatan. Yogyakarta: Nuha Medika.

Arikunto, S. (2010). Prosedur Penelitian Suatu Pendekatan Praktik. Jakarta: Rineka Cipta.A.

Astari, L., Safitri, Y. E., \& P, D. H. (2007). Viral Load pada Infeksi HIV ( Viral Load in HIV Infection ), 31-39.

Astuti, A., \& Budiyani, K. (2010). Hubungan antara dukungan sosial yang diterima dengan kebermaknaan hidup pada ODHA (orang dengan HIV/AIDS). Insight, 1-10.

Bilardi, J. E., Hulme-Chambers, A., Chen, M. Y., Fairley, C. K., Huffam, S. E., \& Tomnay, J. E. (2019). The role of stigma in the acceptance and disclosure of HIV among recently diagnosed men who have sex with men in Australia: A qualitative study. PLoS ONE, 14(11), 1-13. https://doi.org/10.1371/journal.pone.0224616

Cahyadi. (2013). Uji validitas dan reabilitas berger stigma scale versi bahasa indonesia dalam menilai perceived stigma. 
Corrigan, P. W., Bink, A. B., Schmidt, A., Jones, N., \& Rüsch, N. (2016). What is the impact of selfstigma? Loss of self-respect and the "why try" effect. Journal of Mental Health, 25(1), 10-15. https://doi.org/10.3109/09638237.2015.102190 2

Daramatasia, W., \& Soelistyoningsih, D. (2017). Hubungan Jumlah Cd4 Dengan Kualitas Hidup Pada Orang Dengan Hiv/Aids (Odha) Di Jombang Care Center Plus. Media Husada, 8(1). Retrieved from http://ojs.widyagamahusada.ac.id/index.php/JIK /article/download/198/133

Dhea, F., Tandi, W., Asrifuddin, A., Sekeon, S. A. S., Kesehatan, F., Universitas, M., \& Ratulangi, S. (2017). HUBUNGAN KETERBUKAAN ODHA PADA PASANGAN DENGAN TINDAKAN PENCEGAHAN PENULARAN HIV / AIDS ( MELALUI SAFER - SEX DAN PMTCT ) PADA KELUARGA DI KOTA MANADO Immunodeficiency Virus ( HIV ) hamil tahun 2016 sebanyak 0 , $49 \%$ dan jumlah ibu hamil positif yang meme, 7 .

Dinas Kesehatan. (2018). Profil Kesehatan Dinas Kesehatan Kabupaten Jombang 2018. https://doi.org/10.1017/CBO9781107415324.00 4

Ditchman, N., Kosyluk, K., Lee, E.-J., \& Jones, N. (2016). How stigma affects the lives of people with intellectual disabilities: An overview. In Intellectual disability and stigma: Stepping out from the margins. (pp. 31-47). Ditchman, Nicole: Department of Psychology, Illinois Institute of Technology, Chicago, IL, US, nditchma@iit.edu: Palgrave Macmillan. https://doi.org/10.1057/978-1-137-52499-7_3

Egbe, T. O., Nge, C. A., Ngouekam, H., Asonganyi, E., \& Nsagha, D. S. (2020). Stigmatization among People Living with HIV/AIDS at the Kumba Health District, Cameroon. Journal of the International Association of Providers of AIDS Care, 19, 1-7. https://doi.org/10.1177/2325958219899305

Evans-Lacko, S., Gronholm, P. C., Hankir, A., Pingani, L., \& Corrigan, P. (2016). Practical strategies to fight stigma in mental health. In Psychiatry in practice: Education, experience, and expertise. (pp. 237-255). New York, NY, US: Oxford University Press.

Fadli, G. (2015). Gambaran Karakteristik ODHA di Yayasan Lentera Minangkabau Kota Padang. Skripsi.

https://doi.org/10.1377/hlthaff.2013.0625

Finnajakh, A., Meilani, N., \& Setiyawati, N. (2019). Hubungan Tingkat Pengetahuan dan Persepsi dengan Stigma Masyarakat terhadap ODHA di Desa Pandowoharjo, Kecamatan Sleman, Kabupaten Sleman, hal 1,10,11.

Friedman, S. R., Pouget, E. R., Sandoval, M., Rossi, D., MateuGelabert, P., Nikolopoulos, G. K., ... Stall, R. D. (2018). populations : A descriptive and exploratory study, 21(9), 2561-2578. https://doi.org/10.1007/s10461-016-1578-

4.Interpersonal

Goffman, E. (2016). Stigma. Retrieved from http://www.irwish.de/PDF/Goffman/GoffmanStigma.pdf

Gunawan, A. H. (2015). Hubungan Keterbukaan Odha Pada Pasangan dengan Tindakan Pencegahan Penularan HIV/AIDS (Melalui Safer-Sex dan 
PMTCT) Pada Keluarga Oleh Odha. Universitas Muhammadiyah Malang. Retrieved from http://eprints.umm.ac.id/26047/1/jiptummppgdl-alfianhari-38102-1-pendahul-n.pdf

Halli, S. S., Khan, C. G. H., Moses, S., Blanchard, J., Washington, R., Shah, I., \& Isac, S. (2017). Family and community level stigma and discrimination among women living with HIV/AIDS in a high HIV prevalence district of India. Journal of HIV/AIDS and Social Services, 16(1), 4-19. https://doi.org/10.1080/15381501.2015.110779 8

Ibrahim, K., Kombong, R., \& Sriati, A. (2019). The Difference of Perceived HIV Stigma between People Living with HIV Infection and Their Families. Nurse Media Journal of Nursing, 9(2), 117-127.

https://doi.org/10.14710/nmjn.v9i2.24256

Khasanah, N. (2014). Dampak Ekonomi, Sosial Dan Psikologi Hiv / Aids Pada Orang Dengan Hiv/Aids (Odha) Di Kabupaten Kebumen. STIE Putra Bangsa Kebumen, 630-645.

Khububiyah, N. (2018). Hubungan keterbukaan status HIV kepada masyarakat dengan tingkat stres pada ODHA di Jombang Care Center Plus (JCC+). Skripsi.

Kumar, A., Abbas, W., \& Herbein, G. (2014). HIV-1 latency in monocytes/macrophages. Viruses, $6(4)$ 1837-1860.

https://doi.org/10.3390/v6041837

Kusuma, H. (2011). Hubungan Antara Depresi dan Dukungan Keluarga Dengan Kualitas Hidup Pasien HIV/AIDS yang Menjalani Perawatan di RSUP Cipto Mangunkusumo Jakarta. Universitas Indonesia, 20,21,76-79,111-
114,135-139. Retrieved from www.lib.ac.id

Laksana, A. S. D., \& Lestari, D. W. D. (2010). Faktorfaktor Risiko Penularan HIV/AIDS pada Lakilaki dengan Orientasi Seks Heteroseksual dan Homoseksual di Purwokerto. Mandala of Health, 4.

Li, H., Chen, X., \& Yu, B. (2016). Disclosure appraisal mediating the association between perceived stigma and HIV disclosure to casual sex partners among HIV+ MSM: A path model analysis. AIDS Care - Psychological and SocioMedical Aspects of AIDS/HIV, 28(6), 722-725. https://doi.org/10.1080/09540121.2016.114088 4

Llano, M., Saenz, D. T., Meehan, A., Wongthida, P., Peretz, M., Walker, W. H., ... Poeschla, E. M. (2006). An essential role for LEDGF/p75 in HIV integration. Science, 314(5798), 461-464. https://doi.org/10.1126/science.1132319

Lubis, L., Sarumpaet, S. M., \& Ismayadi. (2016). Hubungan Stigma, Depresi Dan Kelelahan Dengan Kualitas Hidup Pasien Hiv/Aids Di Klinik Veteran Medan. Idea Nursing Journal, 7(1).

Mariyamah, S. (2019). Hubungan dukungan keluarga dengan self stigma pada odha di jombang care center (jcc+) kabupaten jombang. Skripsi.

Maryam B. Gainau. (2012). Keterbukaan Diri. Sekolah Tinggi Agama Kristen Protestan Negeri (STAKPN) Papua, 12-36.

Muhammad Saleh Nuwa, Stefanus Mendes Kiik, A. R. V. (2019). Penanganan Terhadap Stigma Masyarakat tentang Orang Dengan HIV/AIDS (ODHA) di Komunitas. Jurnal Penelitian Kesehatan Suara Forikes, 10(1), 49-54. 
https://doi.org/http://dx.doi.org/10.33846/sf.v10 i1.310

Nursalam, Nurs, M., \& Dian, N. (2007). Asuhan Keperawatan Pasien Terinfeksi HIV. Salemba Medika.

Jakarta. https://doi.org/10.1177/140349489502300202

Nyamathi, A. M., Dean, F., Ekstrand, M., Francisco, S., Francisco, S., Angeles, L., ... Delhi, N. (2018). Quality of Life among Women Living with HIV in Rural India, 28(4), 575-586. https://doi.org/10.1016/j.jana.2017.03.004.Qual ity

Overstreet, N. M., Earnshaw, V. A., Kalichman, S. C., \& Quinn, D. M. (2013). Internalized stigma and HIV status disclosure among HIV-positive black men who have sex with men. AIDS Care Psychological and Socio-Medical Aspects of AIDS/HIV, 25(4), 466-471. https://doi.org/10.1080/09540121.2012.720362

Pourmarzi, D., Khoramirad, A., \& Gaeeni, M. (2017). Perceived Stigma in People Living With HIV in Qom. Journal of Family \& Reproductive Health, 11(4), 202-210. Retrieved from http://www.ncbi.nlm.nih.gov/pubmed/3028816 7

Ramadhani, F. R. (2017). Analisis Karakteristik Penderita HIV/AIDS di RS Wahidin Sudirohusodo Makassar. Sripsi. https://doi.org/10.1007/s10551-007-9638-3

Rao, D., Molina, Y., Lambert, N., \& Cohn, S. E. (2017). Assessing Stigma among African Americans Living with HIV. Physiology \& Behavior, 176(1), 139-148. https://doi.org/10.1016/j.physbeh.2017.03.040

Stangl, A., Brady, L., Fritz, K. (2012). Measuring HIV stigma and discrimination; International Centre for Research on Women, Washington D.C., USA. STRIVE Technical Brief.

Suriana, A. (2013). Penelitian tentang. Self Disclosure Pada Pasien ODHA, 01, 1-10.

Syahrina, I. A., \& Pranata, ade yuda. (2018). Stigma Internal Hubungannya dengan Interaksi Sosial Orang dengan HIV/AIDS di Yayasan Taratak Jiwa Hati Padang. Jurnal Fakultas Psikologi Universitas Wisnuwardhana Malang, 22(1), 117. Retrieved from file://C:/Users/Administrator/Downloads/98Article Text-171-1-10-20181114.pdf

Tambunan, M. S. E. (2017). Pengungkapan Diri pada Orang dengan HIV / AIDS ( ODHA ). Skripsi. Retrieved from http://repositori.usu.ac.id/handle/123456789/21 02Downloaded

Thurman, T. R., Kidman, R., Nice, J., \& Ikamari, L. (2015). Family Functioning and Child Behavioral Problems in Households Affected by HIV and AIDS in Kenya. AIDS and Behavior, 19(8), 1408-1414. https://doi.org/10.1007/s10461-014-0897-6

Wahyu, S., Taufik, T., \& Ilyas, A. (2012). Konsep Diri dan Masalah yang Dialami Orang Terinfeksi HIV/Aids. Konselor, 1(2), 1-12. https://doi.org/10.24036/0201212695-0-00

Wang, D., Carroll, G. T., Turro, N. J., Koberstein, J. T., Kováč, P., Saksena, R., ... Steinman, L. (2007). Photogenerated glycan arrays identify immunogenic sugar moieties of Bacillus anthracis exosporium. Proteomics, 7(2), 180184. https://doi.org/10.1002/pmic.200600478

Wang, X., Guo, G., Liang, X., Zhou, L., Zheng, J., Li, 
S., ... Lu, L. (2018). Health Utility of Pregnant Women Living with HIV / AIDS : Prevention of Mother-to-Child Transmission of HIV ( PMTCT

) Programs in Yunnan Province: A CrossSectional Study. Value in Health Regional Issues, 15(309), 27-33. https://doi.org/10.1016/j.vhri.2017.05.004

Widayanti, L. P., Hidayati, S., Lusiana, N., \& Ratodi, M. (2018). Hubungan pengetahuan tentang HIV/AIDS dan sikap mahasiswa terhadap ODHA. Journal of Health Science and Prevention, 2(2), 100-107.

Wiyati, T. G. K. (2019). Hubungan Antara Lama Terdiagnosa Dengan Kualitas Hidup Orang Dengan Hiv / Aids Di Yayasan Victory Plus Tahun 2019 Hubungan Antara Lama Terdiagnosa Dengan Kualitas Hidup Orang Dengan Hiv / Aids Di Yayasan Victory Plus
Tahun 2019. Skripsi.

Xu, X., Sheng, Y., Khoshnood, K., \& Clark, K. (2017). Factors Predicting Internalized Stigma Among Men Who Have Sex with Men Living with HIV in Beijing, China. Journal of the Association of Nurses in AIDS Care, 28(1), 142153. https://doi.org/10.1016/j.jana.2016.08.004

Yuliyanasari, N. (2017). GLOBAL BURDEN DESEASE HUMAN IMMUNODEFICIENCY VIRUS ACQUIRED IMMUNE DEFICIENCY SYNDROME ( HIV-AIDS ), (October 2016), 65-77.

Cite this article as: Pujilestari, Nurullah Ika. dkk. (2020). Hubungan Keterbukaan Status Hiv Dengan Stigma Diri Pada Orang Dengan Hiv/Aids. Media Husada Journal of Nursing Science. Vol. 1 (No.1),31-42. https://doi.org/10.33475/mhjns.vdiisi tim redaksi. 